\title{
DEROGATING REGULATIVE AND ENFORCEMENT POWERS IN COPYRIGHT PROTECTION IN THE DIGITAL MARKET: A TROJAN HORSE FOR THE EU?
}

\author{
Branka Marušić ${ }^{*}$
}

\begin{abstract}
Summary: The proposal for a Directive on Copyright in the Digital Market contains a proposal to harmonise protection of copyright in the digital market and to close the so-called 'value gap'. The value gap is a term that, in the realm of online copyright dissemination, signifies a situation where the right holder (for example, the author of a song) is not adequately remunerated for his or her work. This situation usually occurs when his or her song is made available on an online platform, such as YouTube, and he or she is not paid for the use and enjoyment of the work. The current market mechanism to tackle this problem is done via licensing schemes.
\end{abstract}

This paper will analyse the possible Trojan horse that is hidden in this proposal in order to ask whether, when it comes to online regulation and enforcement of copyright, the deployment of article $114 \mathrm{TFEU}$ is the correct legal basis for the EU to enhance accountability of internet service providers in the regulation and enforcement of copyright.

\section{Introduction}

The European Union legislator, in the light of the new emerging digital market and its Digital Single Market agenda, ${ }^{1}$ proposed two packages of legal reforms in 2016. The second one, which was made available in September 2016, contains a proposal for a new Directive on Copyright in the Digital Single Market. ${ }^{2}$ In this directive, there are several new legislative solutions put forward that aim to harmonise protection of copyright in the digital market and to close the so-called 'value gap'.

The value gap is a term that, in the realm of online copyright dissemination, signifies a situation where the right holder (for example, the

\footnotetext{
LLD Candidate at Stockholm University. Contact: branka.marusic@juridicum.su.se.

1 European Commission, 'Digital Single Market'<https://ec.europa.eu/priorities/digitalsingle-market_en> accessed 6 February 2017.

2 Proposal for a Directive of the European Parliament and of the Council on copyright in the Digital Single Market COM (2016) 593 final - 2016/0280 (COD) (Directive on Copyright in the Digital Single Market).
} 
author of a song) is not adequately remunerated for his or her work. This situation usually occurs when the song is made available on an online platform such as YouTube and the right holder is not paid for the use and enjoyment of the work. A value gap is then created, because the author of the song does not receive any revenue, whereas YouTube as a service receives a steady revenue stream, derived from advertising, and based on the amount of traffic that it attracts. The allure factor for advertisements and the steady revenue stream rest on the number of viewers that visit YouTube services, and the fact that the viewers are attracted to the copyright-protected material that is made available on its platform. ${ }^{3}$

However, the term value gap suffers from some insufficiencies. Firstly, the concept of value, from an economic perspective, suggests that value in copyrighted works should not be entirely ascribed to right holders. The market and social value that the work accrues is measured ${ }^{4}$ differently and evolves over time. In essence, what type of monetary value we ascribe to a work depends on the users' perception of this work. ${ }^{5}$ Secondly, the value might also be linked to the innovation, or inspiration to innovate, that a work might entail. It is argued by some that value also entails the transformative works made by the online platforms, by using the works in new forms, contexts and scenarios, by which the initial works are used as a source of innovation and where the further development of ideas and proliferation of copyright are incentivised. ${ }^{6}$

The current market mechanism to tackle the problem of the value gap is done via licensing schemes. This means that right holders' organisations enter into agreements with platforms in order to safeguard the interest of copyright holders. A typical example of this is YouTube which enters into collective licensing agreements with collecting societies in EU Member States in order to shield itself from right holders' demands to be

\footnotetext{
3 See L Aguiar and J Waldfogel, 'Streaming Reaches Flood Stage: Does Spotify Stimulate or Depress Music Sales?' (2015) Institute for Prospective Technological Studies Digital Economy Working Paper 2015/05 <https://ec.europa.eu/jrc/sites/jrcsh/files/JRC96951. pdf $>$ accessed 17 October 2017.

4 See Sophie Stalla-Bourdillon, 'Filtering Obligations and Fundamental Rights: Can the EU Eat the Cake and Have It Too?' (2017) Better Regulation for Copyright Academics meet Policy Makers Proceedings 24 <https://juliareda.eu/wp-content/uploads/2017/09/2017-09-06_ Better-Regulation-for-Copyright-Academics-meet-Policy-Makers_Proceedings.pdf> accessed 22 November 2017; C Handke, Y Girard, and A Mattes, 'Fördert das Urheberrecht Innovation? Eine empirische Untersuchung, Studien zum deutschen Innovationssystem (2015) 16 Studien zum deutschen Innovationssystem $12<$ https://diw-econ.de/wp-content/uploads/2015/02/StuDIS_16_20151.pdf> accessed 22 November 2017).

5 Philippe Gaudrat, 'The Fundamental Freedom of Amateurs of Art' (2008) 8 Revus: Journal for Constitutional Theory and Philosophy of Law 11.

6 See A Fayolles, Entrepreneurship and New Value Creation: The Dynamic of the Entrepreneurial Process (CUP 2007) 48; D Di Gregorio, 'Value Creation and Value Appropriation: An Integrative, Multi-Level Framework' (2013) 15(1) Journal of Applied Business and Economics 39,40 .
} 
compensated for the use of their material (such as songs, movies, video clips). This compensation is usually done in the form of streamlining part of the advertisement revenue to right holders who have their copyright material placed on the YouTube platform. In Sweden, YouTube entered into a licensing agreement with STIM, ${ }^{7}$ and this trend is visible in other EU Member States, such as Croatia ${ }^{8}$ and Germany. ${ }^{9}$

However, the need to solve the value gap addressed by the concerns of right holders' organisations and collecting societies has been tackled by the online platforms industry. Although in the report made by the International Confederation of Societies of Authors and Composers (CISAC) 10 it is stated that digital services do not create or invest in content and that a transfer of value exists from the creators to the platforms, a Computer \& Communications Industry Association (CCIA) research paper ${ }^{11}$ suggests that digital streaming services enable massive value growth for the right holders. CISAC, in its report, states that the market value of online platforms in the EU was estimated at nearly EUR 22 billion in 2015, yet revenues returned to the right holders for the use of creative content in the digital environment represented only $7.2 \%$ of overall collections in 2016. Moreover, some online platforms do not enter into licence agreements, and for those that do the conditions contained in their agreements differ significantly from the conditions of traditional services, such as television or radio, which might in return jeopardise the value of the rights. However, the CCIA research paper suggests that the music industry had a boost in revenues in 2017, and global collecting societies' revenues grew steadily to reach EUR 8.6 billion in 2015, a 26\% increase since 2008. Between 2010 and 2015, close to half of the growth in collecting societies' income came from digital environment sources. Therefore, the question resurfaced about whether there is even a need to resolve the value gap if market mechanisms are showing a positive trend in resolving it themselves.

\footnotetext{
Lara Brandl, 'YouTube \& Sweden's STIM Reach "Milestone” Licensing Deal (billboardbiz, 20 October 2013) <www.billboard.com/biz/articles/news/global/5763125/youtube-swedens-stim-reach-milestone-licensing-deal> accessed 6 February 2017.

8 Bojan Arežina, 'YouTube i HDS ZAMP sklopili ugovor, glazbenicima prihodi od reklama' Večernji list (Zagreb, 3 November 2014) <www.vecernji.hr/techno/youtube-i-hds-zampsklopili-ugovor-glazbenicima-prihodi-od-reklama-971130> accessed 6 February 2017.

9 'YouTube Strikes Deal with GEMA to Host Music Videos in Germany' (MusicBusiness Worldwide, 1 November 2016) <www.musicbusinessworldwide.com/youtube-strikes-dealgema-host-music-videos-germany/> accessed 6 February 2017.

10 'CISAC Position Paper on the Transfer of Value (CISAC) <www.cisac.org/What-We-Do/ Legal-Policy/CISAC-position-paper-on-the-transfer-of-value> accessed 22 November 2017. 11 Maud Sacquet, 'Value Growth and the Music Industry: The Untold Story of Digital Success' (2017) Computer and Communications Industry Association Research Paper October 2017 <www.ccianet.org/wp-content/uploads/2017/10/CCIA-Paper-Value-Growth-2017. pdf> accessed 22 November 2017.
} 
The new proposal for the Directive on Copyright in the Digital Market contains a proposal to tackle the issue of closing the value gap at the EU level. This proposal essentially seeks to ascertain and legitimise the current market solution in the form of licensing schemes. However, this paper will try to analyse the possible Trojan horse that is hidden in this proposal, in order to ask, when it comes to online regulation and enforcement of copyright, if harmonisation can be achieved under article 114 TFEU $^{12}$ through the enhanced accountability of internet service providers (ISP).

For the purposes of this paper the term 'derogating regulative and enforcement powers' will be addressed through the prism and parameters set by the Court of Justice of the European Union (CJEU) in its case law on when and in what circumstances the EU can delegate some of its powers to independent entities under the provision of article $114 \mathrm{TFEU}$, which serves as a basis for the harmonisation of laws. This will be used as a benchmark to evaluate an inverted situation, where the rules of harmonisation are used to derogate from traditional understanding on how we harmonise rules in the internal market. To be more precise, unlike delegation of powers established in article 114 TFEU, under which the EU either allocates some of its powers to an independent body or harmonises national laws, here there seems to be a situation where harmonisation tools are used for enhancing the accountability of an independent market operator to regulate and enforce copyright online, and essentially advocating self-regulating models and not government controlled ones. Additionally, the notion of derogation of harmonisation powers, for the purposes of this paper, should be linked with the meaning of providing independent entities with the capacity or ability to direct or influence the behaviour of others or the course of events, in an online environment. Due to the fact that harmonisation of intellectual property rights falls into the shared competences of the EU and its Member States, and that the inverted situation of delegation of powers under article 114 addressed in this paper falls in the fluid space between public and private law mechanisms, the term derogation of powers seems more suited to describe the current proposal. This is so because, in the traditional delegation of powers conducted under article 114 TFEU, harmonisation of laws was done mostly in the offline, physical market sphere, and reliance was placed on traditional public law mechanisms in the approximation and harmonisation of laws. In this specific instance, due to the fact that harmonisation tackles issues and market players online, in the digital market sphere, the fluidity between public and private law is more exacerbated and evident, and sometimes these two notions are hard to distinguish. This is

12 Consolidated version of the Treaty on the Functioning of the European Union [2012] OJ C 326 (TFEU). 
more evident if we take into consideration that the regulative landscape of online market players often consists of self-regulating rules of conduct and contractual relationships, which are considered a more private law mechanism. For these purposes, the term derogation of powers seems more apt, because, although the same principles and parameters for delegation of powers could be applied to analyse the legal structure of the proposal, the factual setting is inverted.

This paper will be divided into three parts. The first part will discuss the current regulation and enforcement landscape online in matters concerning copyright. The second part will address the legislative proposal for ISP liability, as well as current parameters and principles which need to be taken into consideration while regulating and enforcing copyright online. The paper will then conclude with an analysis of the effects of the legitimisation of market solutions, specifically taking into consideration (a) whether there is a need to harmonise this field by the EU and to what extent one can enhance the accountability of ISPs; (b) whether ISPs are equipped to provide the same level of protection in an online world that is afforded to actors in an offline setting; and (c) the issue of democratic deficit that occurs when EU deregulates powers to third actors.

\section{The current regulation and enforcement landscape online in matters concerning copyright}

In recent years, the online environment has been at the forefront of the proliferation of ideas, information, content, and a booming digital industry. The wireless thread of the internet changes the way we communicate among each other, how we receive our information, books, clothes, meet our friends and enjoy our free time. The intrusion of this new infrastructure, which we use not only for business but also for leisure, has come to be viewed as a new outlet for the proliferation of content, both by right holders, end users and third parties hosting and storing this content.

Against this backdrop, the issue of how we protect right holders' interests and reward their intellectual endeavour, and not 'break the internet' while doing so, has proven to be quite a task. The intuitive step made by the EU legislator in regulating the online arena was to place liability regimes on the ISPs as intermediary facilitators of the flow of content that occurs between the right holders as suppliers of content and the end users as consumers of this content.

The definition of what an ISP represents is fragmented and often confusing. For the purposes of this paper, two definitions are presented. The first is the definition of an ISP provided by EU law, and the second is the definition of an internet intermediary offered by the Organisation 
for Economic Cooperation and Development (OECD). These two definitions are presented in order to define the scope of the online intermediary actors that are examined in this paper, as well as to exemplify the ISP actors the paper analyses. Additionally, these two definitions are here to illustrate the problem the legislators have in determining online actors and their role in the online digital market.

The E-Commerce Directive ${ }^{13}$ provides for a definition of an ISP as any natural or legal person that provides an information society service. An information society service is defined by three distinctive characteristics. The first is that this service is provided at a distance, which indicates that the parties are not simultaneously present at the same place. The second is that this service is offered via electronic means, which means that the service is initially sent and received at its destination by means of electronic equipment for the processing and storage of data, and entirely transmitted, conveyed and received by wire, radio, optical means or other electronic means. And lastly, that this service is offered and received at the individual request of the recipient of the service, which indicates that the service is provided through the transmission of data on individual request. ${ }^{14}$ It should be borne in mind that in order to fall into the scope of application of the E-Commerce Directive, the information society service must normally be provided for remuneration, although this does not exclude services that are not provided for remuneration.

Riordan suggests ${ }^{15}$ that this definition is narrower than the general class of internet services because it only applies to economic operators and not purely non-commercial activities. This would mean that not all internet intermediaries are caught in the scope of the application of harmonised rules, but only that that meet the above-mentioned criteria. However, being a commercial entity is not a prerequisite to fall under the liability rules. This information is important, because it aids in defining the liability of these actors, which will be discussed later in this paper.

However, for the purposes of illustrating what kinds of ISPs exist, the OECD proposes a more delineated and specific definition, which provides for sub-categories of intermediaries grouped on the basis of the facilitation of transactions between third parties on the internet. This definition proposes six sub-categories of intermediaries: (a) access and service providers; (b) data processors, hosts and registrars; (c) search engines and portals; (d) e-commerce platforms; (e) payment systems; and (f) participative networking platforms. It should be noted that the OECD

13 Directive 2000/31/EC of the European Parliament and of the Council of 8 June 2000 on certain legal aspects of information society services, in particular electronic commerce, in the Internal Market (Directive on electronic commerce) [2000] OJ C178/1 (E-Commerce Directive).

14 ibid, art 2 (a).

15 Jaani Riordan, The Liability of Internet Intermediaries (OUP 2016) 30. 
also recognises the differences between intermediaries that only facilitate the flow of content and those that publish and sell their own content. ${ }^{16}$

The main idea of the above definitional illustrations is to summarise the problem of the allocation of liability for online copyright infringements. In general, when there is an ISP that itself produces content which infringes copyright, then that ISP is liable for the infringement. This is so-called primary liability for copyright infringement which in general terms can be stated as being harmonised at the EU level. However, when the ISP is only a facilitator of the flow of content, then it will not be held liable if it does not have control over the content ${ }^{17}$ (either by knowledge or active participation in the proliferation of that content) ${ }^{18}$ which is transmitted via its platform infrastructure. This is so-called secondary liability, and under the terms of the E-Commerce Directive this general rule only applies to economic operators that fall under the 'safe harbour' provisions of the same Directive. For purposes of clarification, the safe harbour provisions provide for reasons of exclusion of liability that may rise at the national level of Member States, and that have been widely incorporated into the national legislation of Member States for both civil and criminal matters. ${ }^{19}$ The E-Commerce Directive recognises three safe harbour provisions: the 'mere conduit'; ${ }^{20}$ the 'hosting provider;'21 and the 'caching'22 provision. Additionally, there is no general obligation to monitor the content that is stored and transmitted by the ISP under the aforementioned three categories. ${ }^{23}$ It should be reaffirmed here again that the

16 OECD, The Economic and Social Role of Intermediaries (2010) 9-10.

17 Branka Marusic, 'Gate Keeper or Trespasser? EU ISP Liability Regime and Its Privacy Implications' (2016) 1 Nordiskt immateriellt rättsskydd 3.

18 See Case C-324/09 L'Oréal SA,Lancôme parfums et beauté \& Cie SNC, Laboratoire Garnier \& Cie, L'Oréal (UK) Ltd $v$ eBay International AG, eBay Europe SARL, eBay (UK) Ltd, Stephen Potts, Tracy Ratchford, Marie Ormsby, James Clarke, Joanna Clarke, Glen Fox, Rukhsana Bi ECLI:EU:C:2011:474, paras 120 and 124; and Joined Cases C-236/08 to C-238/08 Google France SARL and Google Inc v Louis Vuitton Malletier SA (C-236/08), Google France SARL $v$ Viaticum SA and Luteciel SARL (C-237/08) and Google France SARL $v$ Centre national de recherche en relations humaines (CNRRH) SARL and Others (C-238/08) ECLI:EU:C:2010:159, para 114.

19 Report from the Commission to the European Parliament, the Council and the European Economic and Social Committee - First Report on the application of Directive 2000/31/ EC of the European Parliament and of the Council of 8 June 2000 on certain legal aspects of information society services, in particular electronic commerce, in the Internal Market (Directive on Electronic Commerce) COM/2003/0702 final, para 63.

20 ISPs that transmit information from one point on a network to another at the request of the recipient of the service or that simply provide access to a communication network.

21 ISPs that store information provided by a recipient of a service.

22 The automatic, intermediate and temporary storage of information for the sole purpose of making the onward transmission of that information more efficient.

23 See Stefan Kulk and Frederik Zuiderveen Borgesius, 'Filtering for Copyright Enforcement in Europe after the Sabam Cases' (2012) 34(11) European Intellectual Property Review 791-795. 
safe harbour provisions only apply to ISPs when they are intermediaries of the information (passive facilitators of the flow of content) and not the originators of the information.

For ease of reference, three distinctions should be made regarding the terms of primary and secondary liability. The first relates to the scope of application of primary and secondary liability. While primary liability concerns itself with actors who are directly involved in the infringing activity, secondary liability concerns actors that are infringing copyright in a commercial setting, either by dealing in infringing copies or facilitating infringement (when facilitating infringement, the condition of a commercial setting is not as relevant). The second distinction concerns knowledge of the infringing action. Usually in primary infringement, liability for the infringing act does not yield an assessment of whether the actor concerned had knowledge in order to ascertain infringement. However, in the assessment of secondary liability, it is the knowledge of the fact that an infringing act has occurred that determines whether liability can be ascribed. ${ }^{24}$ Lastly, the standard for the liability regime has been set at an international level and at the EU level. Regarding primary liability, international agreements such as $\mathrm{WCT}^{25}$ and the TRIPS Agreement ${ }^{26}$ provide for the setting of the outer limits of the scope of copyright protection by providing that ideas are not protected under copyright, only the expression of them. This has been implemented through the EU copyright harmonisation framework and national laws of Member States. Additionally, under the CJEU interpretation of copyright infringement, in order for it to occur there needs to be found that 'any part' of the work is reproduced, as long as that part meets the criterion of protection, which means that it is original and the author's own intellectual creation. ${ }^{27}$ In this way, primary liability for copyright infringement at the EU level provides for a standard of adjudication of occurrence where a work (the expression of an idea, and not the idea itself) is infringed. With regards to the secondary liability of the ISPs under the EU law regime, as stated above, it is negatively defined through exclusions of liability. This was done through the E-Commerce Directive, and not a specific copyright harmonising directive because it was recognised by the EU legislator that ISP liability

\footnotetext{
24 Bently Lionel and Sherman Brad, Intellectual Property Law (4th edn, OUP 2014) 217.

25 World Intellectual Property Office Copyright Treaty, adopted 20 Dec 1996, WIPO Do CRNRIDC/94 (WCT) art 2.

26 Agreement on Trade-Related Aspects of Intellectual Property Rights, 15 Apr 1994, Marrakesh Agreement Establishing the World Trade Organization, Annex 1C, the Legal Texts: The Results of the Uruguay Round of Multilateral Trade Negotiations 320 (1999) 1869 UNTS 299, 33 ILM 1197 (1994) (TRIPS Agreement) art 9(2).

27 Case C-5/08 Infopaq International v Danske Dagblades Forening ECLI:EU:C:2009:465, para 74 .
} 
not only pertains to matters of copyright, but that it can also fall into the realm of defamation, hate speech, sale of counterfeit goods and other possible legal bases. Two issues here need to be noted. The first is that the immunity afforded by the safe harbour provisions excludes liability for damages, other monetary remedy, and criminal sanction, but it does not prohibit injunctive relief (an order to stop or remove infringing activities). ${ }^{28}$ And secondly, some courts, such as the European Court of Human Rights (ECtHR) when assessing ISP liability for hate speech (another basis for ISP liability), have been reluctant to go into an analysis of the application of the safe harbour provisions as implemented in the national law of an EU Member State, in order to provide immunity from liability for the ISP. ${ }^{29}$ Therefore, when it comes to the secondary liability of ISPs, there is a lack of harmonisation for injunctive relief at this moment at the EU level, as well as the fact that there exists an adjudicative reluctance to employ the safe harbour provisions across the board for all bases of exclusion of liability.

Although the above contextualisation of ISP liability might portray a situation that provides for a clear-cut delimitation of rights and duties of online actors in copyright enforcement, this picture is merely an illusion. Three points illustrate the problematics of the current situation. Firstly, there is no consensus on what platform should be deemed an ISP for the purposes of the E-Commerce Directive, and this is evaluated on a caseby-case basis. To illustrate, the CJEU recognised in Google France ${ }^{30}$ and $L^{\prime}$ Oreal $v E-B a y^{31}$ that search engines such as Google, and sale and purchase websites such as eBay, are facilitators of the flow of content, and not originators of content, thus falling under the safe harbour provisions, and in a recent case the CJEU recognised that Pirate Bay as an indexing site infringes copyright. ${ }^{32}$ In the case law of the Member States, on a more general level, liability has been excluded in some cases for ISPs such as

\footnotetext{
28 E-Commerce Directive (n 13) recital 45.

29 Delfi AS $v$ Estonia App no 64569/09 (ECtHR 10 October 2013); and Delfi AS $v$ Estonia (GC) App no 64569/09 (ECtHR 16 June 2015); see also ECHR Magyar Tartalomszolgáltatók Egyesülete and Index.hu Zrt v Hungary App no 22947/13 (ECtHR 2 February 2015).

30 Joined Cases C-236/08 to C-238/08 Google France SARL and Google Inc v Louis Vuitton Malletier SA (C-236/08), Google France SARL $v$ Viaticum SA and Luteciel SARL (C-237/08) and Google France SARL $v$ Centre national de recherche en relations humaines (CNRRH) SARL and Others (C-238/08) ECLI:EU:C:2010:159.

31 Case C-324/09 L'Oréal SA, Lancôme parfums et beauté \& Cie SNC, Laboratoire Garnier \& Cie, L'Oréal (UK) Ltd v eBay International AG, eBay Europe SARL, eBay (UK) Ltd, Stephen Potts, Tracy Ratchford, Marie Ormsby, James Clarke, Joanna Clarke, Glen Fox, Rukhsana Bi ECLI:EU:C:2011:474.

32 Case C-610/15 Stichting Brein ECLI:EU:C:2017:456, paras 45 and 48.
} 
YouTube in Italy ${ }^{33}$ and Spain, ${ }^{34}$ as well as Google in France, ${ }^{35}$ and not for Pirate Bay in Sweden. ${ }^{36}$ Furthermore, in order to apply the safe harbour provisions, the ISPs heavily rely on notice and takedown procedures in order to shield themselves from liability. ${ }^{37}$ Secondly, the subject matter of exclusion of liability and with it the degree of assessment of control over content criteria is subject to the national law of Member States which might lead to disparities in the allocation of liability to ISPs. And lastly, the case law of the CJEU provides for vague terms, such as the term diligent economic operator, ${ }^{38}$ which is necessary to identify illegal actions made over its infrastructural platform. However, what the term diligent means is left to the courts and the national law of Member States.

The liability scheme provides an introduction to the question on considering how the enforcement of copyright mechanisms is either supported or inhibited by the broad European regulatory framework for ecommerce. As indicated above, the practical impossibility of pursuing individual infringers has led copyright stakeholders to make efforts to place accountability onto intermediaries. ${ }^{39}$ A general consensus has arisen that ISPs are the best placed party, in both a theoretical and practical sense, to respond to online infringement.

Two approaches exist for assigning this liability of an ISP in relation to copyright infringement; they are characterised as either vertical or horizontal. The vertical approach is characteristic of intellectual property laws in the United States, where liability regimes are each individually applied to different areas of law. In contrast, laws that are characteristic of the horizontal approach to liability are applicable to any form of infringement regardless of the relevant topic of law. This means that laws not only apply to copyright infringement, but also to other laws concerning matters such as privacy and defamation. ${ }^{40}$ This approach is exemplified in the E-Commerce Directive. ${ }^{41}$

\footnotetext{
33 Tribunale ordinario di Torino, causa nrg 15128/2014, Delta TV programs srl c/a Google Ireland Holdings, Google Inc, YouTube, 23 January 2014.

34 Madrid Civil Court of Appeal, case no 505/2012, Gestevision Telecinco c/a YouTube LLC, 14 January 2014.

35 Cour de cassation, chambre commerciale, audience publique du mardi 29 janvier 2013, No de pourvoi 11-21011 11-24713.

36 Case B13301-06 Pirate Bay Stockholm's District Court (17 April 2009) [translation commissioned by IFPI].

37 Christina Angelopoulos and Stijn Smet, 'Notice-and-Fair-Balance: How to Reach a Compromise between Fundamental Rights in European Intermediary Liability' (2016) 8 Journal of Media Law 268.

38 L'Oréal (n 31) para 120.

39 Peter Danowsky, 'The Enforcement of Copyright in a Borderless Online Environment: A Practitioner's View in Copyright in a Borderless Online Environment' in Johan Axhamn (ed), Copyright in a Borderless Online Environment (Norstedts juridik 2012) 127.

40 Angelopoulos and Smet (n 37).

41 Pablo Asbo Baistrocchi, 'Intermediary Service Providers in the EU Directive on Electronic Commerce (2002) 19 Santa Clara Computer \& High Tech Law Journal 111, 117.
} 
As outlined above, the E-Commerce Directive sets out an exoneration scheme for ISP liability at both the civil and criminal level. The public policy reasons behind such liability limitations were said to be in order to preserve freedom of communications, expressions and commerce on the internet. ${ }^{42}$ However, the question remains concerning what the enforcement modalities are that are left to the right holder to secure its interest online. These can be found under the InfoSoc Directive ${ }^{43}$ and the Enforcement Directive. ${ }^{44}$ Under article $8(3)$ of the InfoSoc Directive, Member States are obliged to ensure that right holders can apply for an injunction against intermediaries when their services are used by a third party to infringe a copyright or related right. The Enforcement Directive has a mirroring provision in its article 11 . These injunctions against ISPs can be sought in order to bring infringements to an end, but also to prevent those infringements from occurring in the future. ${ }^{45}$ The modality of these injunctions has taken different forms, such as personal data collection, ${ }^{46}$ website blocking measures, ${ }^{47}$ filtering electronic communications, ${ }^{48}$ or recently the duty to secure access to a Wi-Fi network via a password. ${ }^{49}$ Both the aforementioned directives present a minimum form of harmonisation, and Member States are relatively free regarding the way in which EU level principles are instilled within their own national laws. However, how the provisions of the Enforcement Directive should operate alongside the ECommerce Directive is still largely unclear, despite the fact that under article 2(3) its operation should not affect the E-Commerce or InfoSoc Directive.

In the current context, where ambiguity exists for the implementation of the EU Directives, and consequently for the legal liability of intermediary actors, ISPs embark upon greater self-regulation to find workable solutions for the sake of preserving their own rights and interests. These solutions range from automated takedown mechanisms that are

\footnotetext{
42 Annemarie Bridy, 'Graduated Response and the Turn to Private Ordering in Online Copyright Enforcement' (2010-2011) 89 Oregon Law Review 81, 52.

43 Directive 2001/29/EC of the European Parliament and of the Council of 22 May 2001 on the harmonisation of certain aspects of copyright and related rights in the information society [2001] OJ L167/ 10 (InfoSoc Directive).

44 Directive 2004/48/EC of the European Parliament and of the Council of 29 April 2004 on the enforcement of intellectual property rights [2004] OJ L157/16. Rectification of Directive 2004/48/EC of the European Parliament and of the Council of 29 April 2004 on the enforcement of intellectual property rights (hereinafter: the 'Enforcement Directive').

45 L'Oréal (n 31) para 31.

46 Case C-275/06 Promusicae v Telefónica ECLI:EU:C:2008:54.

47 Case C-314/12 UPC Telekabel Wien GmbH $v$ Constantin Film Verleih GmbH and Wega Filmproduktionsgesellschaft $\mathrm{mbH}$ ECLI:EU:C:2014:192.

48 Case C-70/10 Scarlet Extended SA ECLI:EU:C:2011:771.

49 Case C-484/14 Tobias Mc Fadden $v$ Sony Music Entertainment Germany GmbH ECLI:EU:C:2016:689.
} 
subject to the terms and conditions of the individual service provider, to monitoring mechanisms that might struggle with the identification of infringing content. ${ }^{50}$ This struggle for content identification is more evident if we take into consideration that in a single second online, there are at least 2,580,854 emails sent, 43,731 GB of data transmitted by ISPs, and every minute there are over 400 hours of new videos that are uploaded to YouTube. ${ }^{51}$ Additionally, as industry stakeholders attempt to assign greater accountability for ISPs to execute intensified monitoring and data collection activities for the purposes of enforcing copyright, the application of safe harbour provisions is made all the more problematic.

\section{A new proposal and set of guiding tools in online regulation and enforcement}

September 2016 marked two events that signalled the change in the role of ISPs. The first event was the CJEU decision in the GS Media case $^{52}$ that provided an obligation to maintain a balancing act between right holders and end users, and the second one was the proposal for the Directive on Copyright in the Digital Single Market. Article 13 of the Directive on Copyright in the Digital Single Market provides for the introduction of an obligation to monitor the activity of users through content recognition technologies, to report back to the right holders, and to introduce complaints and redress mechanisms for ISPs that store and give access to large amount of works and other subject matter uploaded by their users. These two instances mean that whoever regulates and enforces copyright online needs to balance the right holder's property rights and the end user's right of freedom of expression and information. This balancing act in itself is hard to achieve at the EU and Member State level while regulating and enforcing copyright. The problem might be even tougher if a margin of discretion exists to allow for this balancing to be placed in the hands of independent market operators, such as ISPs in their 'online policing' capacity. However, this paper will not analyse this issue; rather, it will go into the issue of framing the new accountability regime proposed by the Commission. It should be noted that the current framing of the proposal seems to suggest more detailed rules for the ISPs' accountability

\footnotetext{
50 See Alpana Roy, Althaf Marsoof 'Geo-blocking, VPNs and Injunctions' (2017) 39(11) European Intellectual Property Review 672.

51 See Robert Allen, 'What Happens Online in 60 Seconds' (Smart Insights, 6 February 2017)<www.smartinsights.com/internet-marketing-statistics / happens-online-60-seconds> accessed 15 April 2017; Internet live statistics <www.internetlivestats.com/onesecond/\#email-band> accessed 15 April 2017; Bree Brouwer, 'YouTube Now Gets Over 400 Hours Of Content Uploaded Every Minute' (Tubefilter, 26 July 2015) <www.tubefilter. com/2015/07/26/youtube-400-hours-content-every-minute/> accessed 15 April 2017.

52 Case C-160/15 GS Media BV $v$ Sanoma Media Netherlands BV and Others ECLI:EU:C:2016:644, para 31.
} 
in observing the right holder's rights. The term accountability rather than liability should be stressed here for two reasons. Firstly, deriving from the explanatory memorandum to the proposal, as well as the recitals, ${ }^{53}$ the underlying tone used by the Commission seems to stress the importance of preserving rights rather than sanctioning breaches of rights. Secondly, unlike the wording and framing of the terms in the E-Commerce Directive, this proposal does not put forward either criteria for liability (or lack thereof) or the manner in which this liability should be dealt with.

Taking into consideration the above, this paper will not analyse the compatibility and complementary of the system that is proposed with the current liability regime established under the E-Commerce Directive. Rather, this paper will examine the legitimacy of proposing the de facto legitimisation of the current market mechanisms that solely rest upon the self-regulating landscape of individual ISPs.

\section{Legitimisation of market solutions: what are the issues in derogation of powers?}

The new proposal for the Directive on Copyright in the Digital Single Market uses as its legal basis article 114 TFEU. The idea here is that this article is invoked when the EU legislator aims to harmonise a field of law at the EU level to advance market integration and remove obstacles in the internal market which are made through differing national law enactments and practices.

For purposes of clarification, in order to legislate in any specific area of law, the legislator needs to have competences to embark on such an action. Under the principle of conferral of powers, ${ }^{54}$ the EU is granted legislative competence whenever the Treaties empower it to act, in order to achieve the objectives enshrined in the Treaties themselves. Following this, any legislative act must be based on a Treaty provision, and consequently have a legal basis. However, when harmonising the national laws in the field of copyright, the Treaties are silent on referencing such competence. Since such a specific clause is not found in the Treaties, harmonisation in the field of copyright has been made on the pillars of building the internal market, rather than on a specific copyright-based issue. This is so since trade in copyrighted material, be it embedded or complementary to goods or services, can be hindered by differing national copyright protection regimes. Hence, most of the copyright harmonisation measures in the field of copyright, including the recent copyright legislative package, has been adopted and proposed under article 114 TFEU.

53 Explanatory memorandum to the proposal on the Directive on Copyright in the Digital Single Market 3; Directive on Copyright in the Digital Single Market, recitals 37, 38 and 39.

54 Consolidated version of the Treaty on European Union [2012] OJ C326/1 (TEU) art 5. 
However, article 114 TFEU contains a functional competence rule. ${ }^{55}$ This means that article 114 does not provide any guide regarding what the substantive content of the harmonising measure should be. By means of article 114, the main purpose is to grant competence to enable the establishment and functioning of the internal market, independent of the substantive content or subject matter of the harmonising measure. ${ }^{56}$

Since the nature of article 114 is one of functionality, it has no normative or substantive content. Thus, this provision is quite a flexible competence norm, in the sense that it enables the EU to harmonise a wide range of subjects, as long as these subjects can be linked with the idea of the creation of the internal market. However, this flexibility can be seen as making the harmonisation process dependent on the legislator's discretion, creating a situation of what Weatherill calls competence creep. ${ }^{57}$

The specific issue of competence creep, or the degree of the legislator's discretion, will be addressed through the suggested provision of article 13 of the Directive on Copyright in the Digital Single Market. Focus is placed on this specific article and not the entire copyright reform to illustrate the problem of the protection and enforcement of copyright online.

In this specific case, the framing of the solution of harmonisation hints that the Commission proposes that Member States give room to market mechanisms developed by the ISPs to provide for an environment where ISPs 'cooperate with right holders to ensure the functioning of concluded agreements', 'Member States facilitate the cooperation between ISPs and right holders through stakeholder's dialogue' in order to 'define best practices'. In this way, the traditional paradigm where the EU instructs Member States to regulate a certain area is shifted to a more nuanced and suppressed notion of 'let the market regulate'. What is meant by this is the idea that, although not directly framed, there is an underlying assumption that the current private law mechanisms developed by the ISPs in the form of licensing schemes should be taken from a traditional private law outlook and placed under the umbrella of a public law mechanism in order to highlight their regulative and enforcement role online. The idea here rests on the notion that ISPs are best suited to have the technology and the 'know-how' to find a solution to bridge the value gap problem in copyright. ${ }^{58}$ The rationale is that the one who provides the infrastructure for the creation, dissemination and consequently

\footnotetext{
55 Ana Ramalho, The Competence of the European Union in Copyright Lawmaking: A Normative Perspective of EU Powers for Copyright Harmonization (Springer 2016) 20.

56 S Weatherill, 'Union Legislation Relating to the Free Movement of Goods' in P Oliver (ed), Oliver on Free Movement of Goods in the European Union (Hart Publishing 2010) 639.

57 Ramalho (55) 6-7.

58 Jim Harper 'Against ISP Liability' (2005) 28(1) Regulation 30.
} 
the enabling of copyright infringement would be the one to know how to control these actions.

Due to the fact that in its framing outlook this proposal seems to suggest that Member States should leave the issue of 'policing online copyright infringement' to the market, the basic question is whether the EU can do this under the set parameters of article 114 TFEU. Can this derogation in which there is a need to regulate, but where the legislator is aware of its physical world constraints to wholeheartedly dive into the harmonisation process, even be possible under the current legal boundaries of the employment of article 114 TFEU as a proper legal basis for harmonisation?

The overview of legitimising market solutions will firstly tackle the issue of derogation of powers under article 114 TFEU, providing an analysis on whether this is a correct legal basis for solving the problem of the value gap through EU-wide harmonisation. To further this, the analysis will go into the question of whether the ISPs are equipped to provide the same level of protection in an online world that is afforded to actors in an offline setting. Lastly, the study will touch on the issue of democratic deficit that occurs when EU derogates regulative powers to third actors.

\subsection{Article 114 TFEU as a proper legal basis for closing the value gap}

The legislative solution put forward to solve the value gap issue rests on two pillars. The first pillar provides an appropriate legal basis under EU law to harmonise the field of online copyright and with it to close the value gap problem. The second pillar is the legitimisation of the current content identification technologies and the complaints and redress mechanisms used by ISPs to strengthen the licensing schemes that are concluded between the ISPs and right holders. ${ }^{59}$

In order to evaluate whether article $114 \mathrm{TFEU}$ is the proper legal basis to legitimise the current market solution, two issues need to be highlighted. The first is that article 13 provides for the role of Member States as facilitators of a stakeholder's dialogue between the ISPs and right holders, which occurs in order to find the best mechanisms to ensure the effectiveness of licensing schemes. And, secondly, this role of facilitator essentially places regulative and enforcement power in the hands of the ISPs rather than with the Member States.

In general, article 114 TFEU is regarded as the proper legal basis through the use of directives as legal mechanisms for the harmonisation and approximation of laws at the EU level. However, in order to ap-

59 Directive on Copyright in the Digital Single Market, recital 38. 
ply article 114 TFEU as a proper legal basis, two conditions need to be fulfilled. The first is that the directive needs to adopt measures for the approximation of national provisions, and the second is that these national provisions should aim at the establishment and functioning of the internal market.

Even if we disregard the fact that in the present case we are not strictly dealing with the approximation of national provisions but with the approximation of self-regulating online practices that differ among individual ISPs, we still need to analyse whether article 114 TFEU allows enhanced accountability of online market players, in this instance ISPs. In order to evaluate this issue, two questions need to be answered. The first is whether the EU can make ISPs accountable by placing regulative and enforcement powers upon them, and the second is whether the mechanisms provided in the evaluation and closing of the value gap amount to harmonisation measures envisaged by article 114 TFEU.

\subsubsection{Derogation of powers under article 114 - Quis custodiet ipsos custodes?}

When assessing the derogation of powers of Member States to a specific actor, the criteria established in the Meroni case should be taken into consideration. ${ }^{60}$ Although these criteria were set for the delegation of powers to a specific regulating body, and, in this case, we have a situation where we analyse the enhancing accountability of market operators, and with it derogating the powers of Member States to regulate, the general principles established there can be used for an assessment. This is so for two reasons. Firstly, each ISP creates its own regulative framework for the functioning of its platform, thus effectively making it a self-regulative body for its own slice of the digital market. Secondly, the criteria in the Meroni case provide for a general framework when the EU has competence to provide independent entities with the possibility and the power to direct or influence the behavior of others, which can be used to assess whether the EU has competence to signal to Member States that accountability in the enforcement of copyright online should be placed on the ISPs and not on the Member States themselves.

In the light of the above, the Meroni criteria state that the delegation of powers from the EU to a specific actor is valid in a situation of clearly defined executive powers where the exercise can be subject to a strict review in the light of objective criteria determined by the authority that delegated this power. The validity is brought into question in a situation where there is discretionary power implementing a wide margin of discretion which results in the actual transfer of accountability that essentially

$\overline{60}$ Case 9/56 Meroni v High Authority ECLI:EU:C:1958:7, 152. 
does not provide for the same safeguards that a government would provide, due to the fact that this transfer is to a private actor.

In the current proposal, the enhanced accountability in regulative and enforcement powers to ISPs is not clearly defined and is not subject to a strict review. The above two criteria can be placed in two specific boxes that state that where there is no effective control by the delegating body, in this case the EU or the Member State, due to the shared competences of the field of harmonisation, and no judicial control over the mechanism provided by enhanced accountability, this action should be viewed as invalid.

In this specific case, the legislative solution does not provide for a clear definition of effective control, either by the EU or the Member States, over the choice or manner in which the ISPs regulate the issue of resolving the value gap.

If we observe the literature on accountability, where large volumes have been written predominantly in the fields of political science and law, ${ }^{61}$ the first issue that comes to the fore is the fact that there is no established definition of accountability. However, as some academics point out, ${ }^{62}$ there are two generally accepted aspects. The first is that the agent has to report to a higher authority or principal, and the second is that the higher authority or principal can reward or censor the agent. In both of these aspects, it is the agent who firstly accounts for its conduct, and, secondly, is sanctioned or rewarded based on its demonstrated conduct. However, it should be stressed that an accountable agent must enjoy a certain degree of independence. ${ }^{63}$ It is in this balancing act between accountability and independence that we can assess the idea of effective control of the actions of ISPs by the EU or Member State.

The role of facilitators and mediators that is envisaged in the proposal for Member States provides for the discretionary power of ISPs to use the private law licensing scheme mechanism to establish safeguards different from those provided by Member States. Empowering the licensing schemes through a traditional public law mechanism of directives and national implementing measures still does not tackle the issue that this proposal mainly deals with, the accountability of a market player for safeguarding the interest of right holders, and that the underlying idea of the proposal does not hint at what occurs in a situation when this

61 T Tridimas The General Principles of EC Law (OUP 2000) 163.

62 Phedon Nicolaides and Nadir Preziosi 'Discretion and Accountability: An Economic Analysis of the ESMA Judgment and the Meroni Doctrine' Bruges European Economic Research Papers 30/2014, 4.

63 Miroslava Scholten, 'Accountability vs Independence: Proving the Negative Correlation' (2014) 21(1) Maastricht Journal of European and Comparative Law. 
accountability is either not achieved or breached. Specifically, the question of reporting to the EU or the Member State as the principle in the accountability model on how, when, and in what manner the interests of the right holder are safeguarded is lacking. Thus, the accountability model, placed in the current legislative proposal setting, cannot give an answer to what occurs when the ISPs as agents do not adhere to the specific tasks that were derogated to them.

The balancing act of accountability and independence of ISPs can be tested on a specific important safeguard, relevant for all market players, and that is the safeguard of legal certainty, which presumes knowledge of rules in order for actors to align their behaviour. ${ }^{64}$ Due to the fact that licensing schemes, specifically those that YouTube concludes with collecting societies in Member States, are often covered by non-disclosure clauses, these private law mechanisms deprive third parties, such as end users, of the knowledge of rules, as well as the opportunity to adjust their online behaviour. In this way, the balance tips to the independent side of ISP conduct, thus diminishing accountability in this scheme, rendering the effective control of the principle over the actor unenforceable.

Furthermore, the judicial control of the enforcement of regulative powers is again left to the discretion of the ISPs. The complaints and redress mechanisms are done via the ISPs, and Member States are there to ensure that the ISPs have them. How Member States ensure this judicial review, which is done through a different alternative dispute resolution mechanism to the one provided by Member States, and what kinds of objective criteria are placed on the assessment of breaches of copyright, are unknown factors. Furthermore, the interplay between the alternative dispute forum provided by the ISPs and the judicial forum provided by the Member States might be problematic. The derogation of powers from the EU to Member States in this specific instance of judicial control is still at its outset heavily dependent on the mechanism developed by the ISPs that are at this stage purely automated services that do not take into consideration exceptions and limitations to the copyright protection developed at the EU and national levels of Member States. Moreover, the question of who is 'more' competent to extend the review, and when state judicial power comes to the fore, becomes more prominent. This situation also creates a problem for the standard of legal certainty, because the online actors might find themselves in a situation of not knowing to whom to address their complaint, or a scenario might arise in which there are two competing overlapping adjudicative competences which might come

64 See also M Bovens, 'Analysing and Assessing Accountability: A Conceptual Framework' (2007) 13(4) European Law Journal 447; M Maggetti, K Ingold and F Varone, 'Having Your Cake and Eating It Too: Can Regulatory Agencies Be Both Independent and Accountable?' (2013) 19(1) Swiss Political Science Review 1. 
to different conclusions and yield different results. It is therefore difficult to ascertain that the second criterion of the Meroni doctrine, of effective judicial control that is subject to strict review in the light of objective criteria determined by the authority that delegated this power, is met.

\subsubsection{Harmonisation measures envisaged by article 13 of the Directive on Copyright in the Digital Single Market}

In order for a harmonisation measure to be considered valid, a clear constitutional limit for the EU has been placed on the employment of article 114 TFEU. ${ }^{65}$ This constitutional limit consists of two factors. The first is a very general and broad one which states that the measure needs to improve the conditions for the establishment and functioning of the internal market. The second clarifies that the adoption of a measure is justified under article 114 TFEU if the aim is to prevent obstacles to trade resulting from the diverse development of national laws. However, mere disparity is not enough, since there must be a direct effect on the functioning of the internal market. ${ }^{66}$

The question here amounts to whether the proposed measure to close the value gap, under the proposal of the Directive on Copyright in the Digital Single Market, can be characterised as a harmonisation measure under the constitutional restraints of EU law. The key factor in this analysis is whether the national laws of Member States have been divergent to such a degree to create disparities in the internal market, and the clear answer is no. It was the silence of the laws, rather than their volume, that caused the ISPs to self-regulate their behaviour online. And, consequently, self-regulation created a divergence of solutions, in the form of the regulative mechanisms of the individual ISPs that created obstacles to trade on the digital internal market.

The proposal to solve the value gap does not tackle the need for a uniform approach in harmonising this field; it only goes as far as to suggest the facilitating role of Member States in finding the best solution, which will be left to the market. Although the legislator has a wide margin of discretion in choosing the appropriate harmonisation measure, ${ }^{67}$ that measure still needs to be substantiated by at least a clear vision. With this proposal, no clear vision exists of what kind of harmonisation is taking place, what kind of measure will be taken in order to ensure the uniform application of EU law, and how the divergent approach will

65 Case C-376/98 Germany $v$ Parliament and Council (Tobacco advertising) ECLI:EU:C:2000:544, paras 83 and 86.

66 Case C-210/03 Swedish Match ECLI:EU:C:2004:802, para 29.

67 Miroslava Scholten and Marloes Van Rijsbergen, 'The ESMA-Short Selling Case Erecting a New Delegation Doctrine in the EU upon the Meroni-Romano Remnants' (2014) 41(4) Legal Issues of Economic Integration 400. 
be solved through this proposal. Therefore, it does not fulfil the criteria of constitutional constraint placed on the use of article 114 TFEU in the approximation of laws and does not serve as a proper legal basis for the enactment of the proposed value gap solution under article 13 of the Directive on Copyright in the Digital Single Market. However, there might be a case to justify this harmonising action under article 352 TFEU, which contains a provision on the residual competence of the EU to legislate in cases where it is necessary for the EU to adopt an act to attain objectives laid down by the Treaties when the latter have not provided the powers of action necessary to attain them (such as the need to close the value gap). The justification for harmonising action under article 352 TFEU is not the subject of analysis in this paper. However, it should be noted that article 352 has been employed before in the realm of the harmonisation of intellectual property rights, but as a legal basis for the creation of unitary registered rights, such as community trade mark and design. Since the entry into force of the Lisbon Treaty, the new article 118 TFEU that provides for the creation of unitary intellectual property rights at the EU level has been used instead, for example for the establishment of the unitary patent, leaving article 352 to be re-examined as the proper legal basis for harmonising action in the realm of intellectual property rights.

\subsubsection{Democratic deficit in the enactment of regulation and enforcement of rights online}

The above-mentioned two issues deal with the possibility to use article 114 as a valid legal basis for the derogation of power to ISPs. However, even if this article served as a proper legal basis, the question remains whether this proposal has democratic legitimacy and, with it, whether the EU has a mandate to regulate. To understand democratic legitimacy, several factors need to be taken into consideration. Firstly, democratic legitimacy rests on the idea of principles and procedures that are followed, under which collectivised and binding decisions must be accepted by those who have not participated in making them. ${ }^{68}$ Essentially, it is a topdown procedure made by democratically elected bodies that enact rules to be followed by citizens. However, at an EU level, involving EU citizens in the full range of decision-making processes of EU policies would be an undue burden. Therefore, in this kind of situation it is often presumed that individuals lack the proper knowledge to pursue their interest, so these tasks are delegated to elected political authorities who are then under the obligation to carry out these tasks effectively. ${ }^{69}$

\footnotetext{
68 Stefano Bartolini, 'The Nature of the EU Legitimacy Crisis and Institutional Constraints: Defining the Conditions for Politicisation and Partisanship' in Olaf Cramme (ed), Rescuing the European Project: EU Legitimacy, Governance and Security (Policy Network 2009) 57.

69 Andrew Moravcsik, 'Is There a "Democratic Deficit" in World Politics? A Framework for Analysis' (2004) 39(2) Government and Opposition 336, 344.
} 
Secondly, although the democratic legitimacy of the EU has been heavily criticised, the fact that each Member State has agreed to transfer some of its legislative powers and with it its legislative sovereignty to the EU still stands. Some academics ${ }^{70}$ have chosen to call this a hybrid polity that derives much of its legitimacy from the nation-state governments.

However, what the constitutional framework of the Treaties did not envisage was the transfer of power from the Member States to the EU, and from the EU to independent, unaccountable market players in the form of ISPs. And in this transfer of powers lies the democratic deficit and consequently the lack of mandate of this legislative proposal. It is characterised by the simple fact that the regulation and enforcement of the solution to tackle the online value gap is in principle left to a third actor that was not envisaged either by the founding Treaties of the EU, the Member States that subscribe to these Treaties, or EU citizens.

\section{Conclusion}

On the eve of the last day of war between the city of Troy and the Greeks, the Greeks decided to offer a gift to the city of Troy. This gift was supposed to signal the surrender of the Greeks, and the victory of Troy. The gift was a wooden horse. Troy's priest Laocoön took a look at this offer and stated: 'Quidquid id est, timeo Danaos et dona ferentes'. ${ }^{71}$ And he was right. The Greeks used the wooden horse to conquer the city of Troy.

In the current legislative proposal on copyright reform, the ISPs were offered a gift by the EU legislator. This gift was to enhance the accountability of ISPs in the online enforcement of copyright. The gift should be viewed from two perspectives. The first perspective entails the notion that each ISP and its pertaining infrastructural platform is a 'city state' or 'polis' in itself, and that the ISP itself writes, observes and enacts rules applicable for its own polis and its own population (users). The second one entails the competence of the EU to derogate powers and enhance the accountability of the ISPs. As stated in the introduction of this paper, this derogation of powers has three components, which makes it an unusual choice of regulation. The first component concerns the fact that under the umbrella of shared competences the EU chooses to imply to Member States that certain types of regulation need to be left to the market. With this, there exists a certain validation that the entities that make the fabric of the online infrastructure are best suited to control actions that arise on that infrastructure. The second component concerns the fact that the employment of this type of regulation can compromise the legal certainty

\footnotetext{
70 Michael Longo and Philomena Murray, "No Ode to Joy? Reflections on the European Union's Legitimacy' (2011) 48(6) International Politics 667, 686.

71 Eng 'Whatever happens, I fear the Greeks, even when they bring gifts'.
} 
standard established under EU and Member States legal regimes. When we validate specific regulative solutions, we also validate their intrinsic problems. The intrinsic problems connected to the ISPs' self-regulating model are most prominently the lack of legal certainty in formulating the online behaviour of parties, which is mostly due to the fact that this formulation of online behaviour is done through licensing schemes which fall under the terms of secrecy through non-disclosure clauses for some actors (such as end users). Further, the parallel network of alternative dispute resolution mechanisms brings to the fore the issue of adjudicative competences and the possibility of disparities in the criteria used to determine the scope of copyright protection (as well as copyright infringement). The third component tackles the issue of a mandate to regulate in the online arena. If such a mandate was not envisaged, can a unilateral decision to bring about order where there is none or very little create a mandate on its own?

Perhaps the solution for tackling the problem of the value gap should be solved by the market itself via private strategies for the enforcement of copyright, with the appropriate exoneration from liability that could be clarified either by the CJEU or the legislator by modernising the E-Commerce Directive, and effectively applied at the Member State level. This in turn will provide greater clarity for all copyright stakeholders, and will free relevant parties from the legal limbo they are currently attempting to operate within online. Providing yet another piece of EU harmonising legislation that raises more questions than solutions would only add to the problem of delimiting online ISP liability and the lack of legal certainty for market players. 